\title{
The Woodchuck, a Nonprimate Model for Immunopathogenesis and Therapeutic Immunomodulation in Chronic Hepatitis B Virus Infection
}

\author{
Michael Roggendorf, Anna D. Kosinska, Jia Liu, and Mengji Lu \\ Institute for Virology, University of Duisburg-Essen, 45122 Essen, Germany \\ Correspondence: michael.roggendorf@uni-due.de
}

\begin{abstract}
The woodchuck hepatitis virus (WHV) and its host, the eastern woodchuck, is a very valuable model system for hepatitis B virus infection. Many aspects of WHV replication and pathogenesis resemble acute and chronic hepatitis B infection in patients. Since the establishment of immunological tools, woodchucks were used to develop new therapeutic vaccines and immunomodulatory approaches to treat chronic hepadnaviral infections. Combination therapy of nucleos(t)ide analogs, with prime-boost vaccination and triple therapy, including immunomodulatory strategies by blocking the interaction of the programmed death-1 (PD-1) receptor with its ligand inducing a potent T-cell response in chronic WHV carrier woodchucks, suppression of viral replication, and complete elimination of the virus in 30\% of the animals. Both strategies may be used for future therapies in patients with chronic hepatitis B.
\end{abstract}

$T_{n}^{\mathrm{h}}$ he Eastern woodchuck (Marmota monax) is naturally infected by woodchuck hepatitis virus (WHV), which was discovered in 1978. Early development of hepatocellular carcinoma (HCC) in wild-caught woodchucks within 1 or 2 years of age led to the discovery of WHV (Summers et al. 1978). In contrast to development of HCC in patients, a frequent integration of the WHV genome close to the N-myc and c$m y c$ genes has been observed in the woodchuck (Moroy et al. 1986). WHV was found to be closely related to hepatitis B virus (HBV) (Galibert et al. 1981) and classified as a member of the genus orthohepadnavirus, family hepadnaviridae. However, these viruses differ from each other in several aspects (e.g., regulation of transcription) (Di et al. 1997). Infections of woodchucks with WHV have been shown to be endemic in the Mid-Atlantic states of the United States (e.g., Delaware, Maryland, Pennsylvania), whereas in the State of New York and in New England, woodchucks are rarely infected with WHV. Recently, Chinese Marmota species, genetically related to Marmota monax himalayana, Marmota baibacina, and Marmota bo$b a k$, were tested for their susceptibility to WHV infection. The results showed that M. himalayana is susceptible to WHV infection as all inoculated animals became positive for antiWHV core (WHc), WHV surface antigen

Editors: Christoph Seeger and Stephen Locarnini

Additional Perspectives on Hepatitis B and Delta Viruses available at www.perspectivesinmedicine.org

Copyright (C) 2015 Cold Spring Harbor Laboratory Press; all rights reserved; doi: 10.1101/cshperspect.a021451

Cite this article as Cold Spring Harb Perspect Med 2015;5:a021451 
M. Roggendorf et al.

(WHsAg), and WHV DNA. WHV replication intermediates and proteins were detected in liver samples. M. bobak species showed a limited susceptibility to WHV (Wang et al. 2011). In contrast, M. baibacina remained negative for all tested virological parameters. These data indicate that $M$. himalayana is phylogenetically closely related to $M$. monax. Therefore, these Chinese Marmota species can be explored as a model for hepadnaviral infection and prevention of infection (Wang et al. 2014) and in the future for the new therapies. In contrast to these findings, transmission of WHV to alpine marmots was not successful (Chomel et al. 1984).

The molecular characterization of WHV and experimental infection of woodchucks with WHV have been of great value in modeling several aspects of hepadnaviral infection in humans. Many questions of hepadnaviral infection have been addressed in this model, for example, natural course of infection (Kajino et al. 1994; Cote et al. 2000; Guo et al. 2000; Yamamoto et al. 2002) and immunpathogenesis (Menne et al. 1997, 1998, 2002b; Nakamura et al. 2001; Frank et al. 2007), including innate and adaptive immune responses, host and viral factors associated with development of chronicity.

In chronic WHV infection, a limited intrahepatic interferon (IFN)- $\alpha$ response, intrahepatic markers associated with T-cell exhaustion, elevated levels of suppressor of cytokine signaling 3 (SOCS3) in the liver, and intrahepatic accumulation of neutrophils was observed, as in chronic HBV infection. In addition, WHVinduced HCC shares characteristics with human HCC. These data indicate that immune pathways play a major role either in the persistence of HBV infection or the sequelae of chronic hepatitis B (CHB) (Benhenda et al. 2009). Occurrence and significance of viral mutants in acute and chronic infections has also been studied in detail ( $\mathrm{Li}$ et al. 1996; Botta et al. 2000; Zhang et al. 2001; Lu et al. 2002; Yamamoto et al. 2002).

From a medical point of view, the woodchuck model has been used to develop new strategies for prevention of infection (Lu et al. 1999; Garcia-Navarro et al. 2001)—post-expo- sure prophylaxis of hepatitis B and therapy of chronic hepadnaviral infection, including nucleoside analogs (Cullen et al. 1997; Mason et al. 1998; Genovesi et al. 2000; Korba et al. 2000; Peek et al. 2001), non-nucleoside analogs (Block et al. 1998), therapeutic vaccination (Hervas-Stubbs et al. 2001; Lu and Roggendorf 2001; Menne et al. 2002a), and gene-therapeutic approaches for treatment of HCC (Putzer et al. 2001). Liver transplantation has recently been established for woodchucks to study early events in reinfection and adoptive immune transfer (Dahmen et al. 2004). Lately, significant progress has been made in this model to show that both noncytotoxic and cytolytic antiviral immune responses are needed for elimination of the virus from hepatocytes or to at least control viral replication.

This review, therefore, focuses on immunomodulatory therapies for chronic hepadnaviral infection, including cloning and characterization of additional genes related to innate and adaptive responses, the recent development of new tools to investigate virus-specific T-cell responses, therapeutic vaccines, and, finally, immunomodulatory approaches to treat chronic WHV infections. These new insights in modulation of immune response to WHV in this animal model will enable the development of new strategies to treat chronic HBV infection in patients.

\section{CLONING AND CHARACTERIZATION OF COMPONENTS OF THE WOODCHUCK IMMUNE SYSTEM}

In recent years, a number of immune functionrelated genes in woodchucks have been cloned and characterized. These genes include cytokines and their receptors, immune cell-surface markers, and other immune function-related proteins. In general, the woodchuck genes are more closely related to human than to mouse homologs.

Important woodchuck cytokines and their receptors that have been cloned so far are summarized in Table 1. Among them, tumor necrosis factor (TNF)- $\alpha$, IFN- $\alpha$, IFN- $\gamma$, interleukin (IL)-8, IL-12, IL-15, granulocyte-macrophage 
The Woodchuck as a Model for Chronic HBV Infection

Table 1. Cloned cytokines of woodchuck

\begin{tabular}{|c|c|c|c|c|c|}
\hline & Size & $\begin{array}{c}\text { Homology (aa) } \\
\text { human/mouse (\%) }\end{array}$ & $\begin{array}{c}\text { Biological } \\
\text { activity }\end{array}$ & $\begin{array}{l}\text { Accession } \\
\text { number }\end{array}$ & References \\
\hline TNF- $\alpha$ & 233 aа & $80 / 84$ & + & Y14137 & $\begin{array}{l}\text { Lohrengel et al. 1998, } \\
2000\end{array}$ \\
\hline IFN- $\gamma$ & 166 aa & $60 / 43$ & + & Y14138 & $\begin{array}{l}\text { Lohrengel et al. 1998; } \\
\text { Lu et al. } 2002\end{array}$ \\
\hline IFN- $\alpha$ & 167 aa & $62 / 58$ & + & $\begin{array}{l}\text { AAG27516 } \\
\text { AAK19944 }\end{array}$ & $\begin{array}{l}\text { Salucci et al. 2002; Lu } \\
\text { et al. } 2008 \mathrm{~b}\end{array}$ \\
\hline IFNAR1 & 553 aa & & + & JN379357 & Fan et al. 2012 \\
\hline IL-2 & Partial & & & AF082496 & M Lu, unpubl. \\
\hline IL-4 & Partial & & & AF082495 & M Lu, unpubl. \\
\hline IL-6 & 207 aa & $49 / 46$ & N.D. & Y14139 & Lohrengel et al. 1998 \\
\hline IL-10 & 178 aа & $80 / 72$ & N.D. & AF012909 & Li et al. 2000 \\
\hline IL-12, p35 & 223 aa & $62 / 51$ & + & X97018 & Berraondo et al. 2002 \\
\hline IL-12 p40 & 325 aа & $78 / 65$ & + & X97019 & Berraondo et al. 2002 \\
\hline IL-15 & 192 aа & $79 / 70$ & + & AY426605 & Wang et al. 2005 \\
\hline GM-CSF & 138 aа & $63 / 49$ & + & AF255734 & Wu et al. 2001 \\
\hline Lymphotoxin- $\alpha$ & 202 aa & $78 / 80$ & + & AF095586 & Li et al. 2000 \\
\hline Lymphotoxin- $\beta$ & 306 aa & $67 / 69$ & N.D. & AF095587 & Li et al. 2000 \\
\hline Fas ligand & Partial & & N.D. & AF152368 & Hodgson et al. 1999 \\
\hline IL-8 & 101 aа & $79 /-$ & + & EU332349 & Liu et al. 2009 \\
\hline IP10 & 98 aa & & & EU564728 & Zhang et al. 2009 \\
\hline CCR7 & 378 aa & & & EU924211 & Z Meng, unpubl. \\
\hline IL-10R & 576 aа & & + & JN122322 & Jiang et al. 2012 \\
\hline
\end{tabular}

aa, Amino acid; TNF, tumor necrosis factor; IFN, interferon; IFNAR, interferon receptor; IL, interleukin; N.D., not determined; GM-CSF, granulocyte-macrophage colony-stimulating factor.

colony-stimulating factor (GM-CSF), lymphotoxin (LT)- $\alpha$, and IL-10R have been tested for their biological activities (Lohrengel et al. 1998, 2000; Li et al. 2000; Garcia-Navarro et al. 2001; Wu et al. 2001; Lu et al. 2002; Wang et al. 2005; Liu et al. 2009; Jiang et al. 2012). The entire open reading frame (ORF) of IFN- $\alpha$ was cloned under control of the cytomegalovirus (CMV) promoter into the expression vector PVIJ, and the biological action of IFN- $\alpha$ was shown by inducing expression of MxA-protein. IFN- $\alpha$ was also shown to reduce WHV surface antigen expression in a dose-dependent fashion in WHV-infected woodchuck hepatocytes (Salucci et al. 2002). The same group also refined the analysis of the IFN- $\alpha / \beta$ system of the woodchuck and studied the expression of woodchuck (w)IFN- $\alpha / \beta$ in peripheral blood lymphocytes (PBLs) from naïve and WHV-infected woodchucks (Lu et al. 2008b). The woodchuck IFN- $\alpha$ genes could be classified into 10 subtypes and three pseudotypes. The woodchuck IFN- $\alpha$ subtypes 1,4 , and 5 were found to be produced by poly(I:C)-stimulated woodchuck PBLs, indicating a selective expression of woodchuck IFN- $\alpha$ subtypes. PBLs from chronically WHVinfected woodchucks showed a reduced ability to produce woodchuck IFN when stimulated with poly(I:C). The complete or partial sequences of the type I IFN receptors (IFNARs) of woodchucks were also obtained and analyzed by Fan et al. (2012). IFNAR2 was significantly up-regulated in primary woodchuck hepatocytes stimulated with IFN- $\alpha$ or IFN- $\gamma$. The expression of woodchuck IFNAR1 and IFNAR2 was decreased in woodchucks chronically infected with WHV. These studies are essential for studying type I IFN-related innate immunity and therapy in hepadnaviral infection in the woodchuck model. The biological activities of TNF- $\alpha$ and LT- $\alpha$ were tested in a cytotoxicity assay, and both cytokines showed cytotoxic activities on both mouse L929B and woodchuck A2 cells in the presence of actinomycin D ( Li et 
M. Roggendorf et al.

al. 2000). The biological activity of woodchuck IFN- $\gamma$ was characterized by Lu et al. (2002). It has been shown that recombinant woodchuck IFN- $\gamma$-protected woodchuck cells against infection with murine encephalomyocarditis virus in a species-specific manner. IFN- $\gamma$ could up-regulate the mRNA level of the woodchuck major histocompatibility complex class I (Mamo-I) heavy chain in woodchuck WH12/6 cells and regulated differential gene expression of interferon-induced genes. However, levels of WHV replication intermediates and RNAs in persistently WHV-infected primary woodchuck hepatocytes did not change despite treatment with high doses of IFN- $\gamma$ (Lu et al. 2002). IL-10 is a pleiotropic cytokine acting on a variety of immune cells through the cell-surface receptor (IL-10R). It has been suggested to resuscitate antiviral immunity by interfering with IL-10/ IL-10R pathways. Very recently, Jiang et al. (2012) successfully cloned woodchuck IL-10R and generated antibodies against this molecule. The blockade of woodchuck IL-10R showed the ability to enhance the proliferation and degranulation of specific $\mathrm{T}$ cells from chronically WHV-infected woodchucks in vitro (Jiang et al. 2012).

Important woodchuck immune cell-surface markers that have been cloned so far are summarized in Table 2. The complete coding region of woodchuck T-cell markers, such as CD4, CD28, and cytotoxic T-lymphocyte-associated antigen 4 (CTLA-4), have been cloned and sequenced (Zhou et al. 1999; Yang et al. 2003). CD28 and CTLA-4 are known to play important roles for the regulation of T-cell activation by delivering the costimulation signals. Woodchuck CD28 showed a similarity of $70 \%-80 \%$ to its mammalian homologs according to the deduced amino acid sequences. Woodchuck CTLA-4 has a higher similarity of $74 \%$ to the corresponding mammalian CTLA-4 molecules. The strict conservation of critical amino acid residues like cystein and asparagine residues in woodchuck CD28 and CTLA-4 suggests that both molecules may structurally resemble their human or mouse homologs. A hexapeptide motif MYPPPY, which is believed to be essential for the interaction with CD80, is present in both woodchuck CD28 and
CTLA-4 (Yang et al. 2003). Sequence information of woodchuck CD3, CD4, and CD8 have been used to determine the kinetics of the influx of $\mathrm{T}$ cells into the liver during the incubation period and during acute or chronic WHV infections. In week two postinfection, an influx of $\mathrm{CD}^{+}$lymphocytes could be observed and reached higher levels prior and during the recovery phase. The peak level of $\mathrm{CD}^{+}$and $\mathrm{CD}^{+} \mathrm{T}$ cells coincided with recovery. During transient infection, T cells can accumulate in the liver and reach up to two-thirds of the total number of liver cells (Guo et al. 2000).

Toll-like receptors (TLRs) have been identified as key regulators of innate and adaptive immune responses in viral infection. Recent progress in this field revealed that there are significant interactions between the TLR system and pathogens in chronic viral infections. Woodchuck TLRs that have been cloned so far are summarized in Table 2. In a recent study, Zhang et al. showed that TLR2 ligands activated NF- $\mathrm{B}, \mathrm{PI} 3 \mathrm{~K} / \mathrm{Akt}$, and different arms of mitogen-activated protein kinases (MAPK) signaling pathways and induced the production of proinflammatory cytokines in woodchuck hepatocytes. TLR2-mediated innate immune responses led to reduction of HBV and WHV replication and gene expression in HepG2.2.15 cells and primary woodchuck hepatocytes, respectively. In the woodchuck model, relatively low levels of TLR2 expression were found in peripheral blood mononuclear cells (PBMCs) and in liver tissues from chronic WHV carriers. TLR2 expression in PBMCs was inversely correlated with WHV DNA titers in acute WHV infection and in entecavir-treated chronic WHV carriers (Zhang et al. 2012).

Although progress has been made in cloning and characterizing woodchuck components of the woodchuck immune system, the sequence information is still limited compared with what is known in humans and mice. To address this major limitation of the model, Fletcher et al. (2012) performed the sequencing, assembly, and annotation of the woodchuck transcriptome, together with the generation of custom woodchuck microarrays. By using this new platform, they characterized the transcrip- 
The Woodchuck as a Model for Chronic HBV Infection

Table 2. Clonal cell-surface marker and other genes related to the woodchuck immune system

\begin{tabular}{|c|c|c|c|c|}
\hline Gene & $\begin{array}{l}\text { Sequence } \\
\text { information }\end{array}$ & $\begin{array}{c}\text { Homology }(\mathrm{aa}) \\
\text { human/mouse }(\%)\end{array}$ & $\begin{array}{c}\text { Accession } \\
\text { number }\end{array}$ & References \\
\hline $\mathrm{CD} 3-\gamma$ & Partial & & AF082493 & Guo et al. 2000 \\
\hline $\mathrm{CD} 3-\varepsilon$ & Partial & & $\mathrm{AF} 232727$ & Michalak et al. 2000 \\
\hline $\mathrm{CD} 4$ & 455 aа & & AF082497 & $\begin{array}{l}\text { Zhou et al. 1999; } \\
\text { M Fiedler, unpubl. }\end{array}$ \\
\hline CD8 & Partial & & AF082499 & Zhou et al. 1999 \\
\hline $\mathrm{CD} 28$ & 221 aa & $76 / 74$ & AF130427 & Yang et al. 2003 \\
\hline CTLA-4 & 223 aа & $86 / 85$ & AF130428 & Yang et al. 2003 \\
\hline MHC-I, Mamo-I & 359 aa & $81-83 / 78-79$ & AF146091 usw & Yang et al. 2003 \\
\hline MHC II, WLA & 266 aa & $87 / 80$ & & S Viazov, unpubl. \\
\hline B2 microglobulin & Partial & & AF232726 & Michalak et al. 2000 \\
\hline TAP-1 & Partial & & AF232724 & Michalak et al. 2000 \\
\hline TAP-2 & Partial & & AF232725 & Michalak et al. 2000 \\
\hline $2^{\prime}-5^{\prime}$ oligoadenylate synthetase & Partial & & AF082498 & Zhou et al. 1999 \\
\hline Stat4 & Partial & & AY177676 & Wang et al. 2003 \\
\hline Stat6 & Partial & & AY177677 & Wang et al. 2003 \\
\hline T-bet & Partial & & AY177675 & Wang et al. 2003 \\
\hline GATA-binding protein 3 & Partial & & AY 177678 & Wang et al. 2003 \\
\hline PemI & Partial & & AY494083 & Fourel et al. 1994 \\
\hline Perforin & Partial & & AF298158 & Hodgson et al. 1999 \\
\hline Tumor suppressor p53 & 391 aа & $86 / 77$ & AJ001022 & Feitelson et al. 1997 \\
\hline Foxp3 & Partial & & EU168437 & Crettaz et al. 2009 \\
\hline PD-L1 & 229 aа & & HQ403652 & Zhang et al. 2011 \\
\hline PD-L2 & Partial & & EU306521 & Zhang et al. 2011 \\
\hline CD14 & Partial & & EF621769 & CS Guy, unpubl. \\
\hline CD56 & Partial & & EF621771 & CS Guy, unpubl. \\
\hline CD40L & Partial & & EF621770 & Guy et al. 2008 \\
\hline CD1d & Partial & & EF621767 & Guy et al. 2008 \\
\hline $\mathrm{CD} 40$ & 280 aa & & EU586561 & E Zhang, unpubl. \\
\hline CD107a & 322 aa & & EF159727 & Frank et al. 2007 \\
\hline TLR2 & Partial & & HQ446273 & X Zhang, unpubl. \\
\hline TLR3 & Partial & & EU586552 & Zhang et al. 2009 \\
\hline TLR4 & Partial & & EU586553 & Zhang et al. 2009 \\
\hline TLR7 & Partial & & EU586554 & Zhang et al. 2009 \\
\hline TLR8 & Partial & & EU586555 & Zhang et al. 2009 \\
\hline TLR9 & Partial & & EU586556 & Zhang et al. 2009 \\
\hline
\end{tabular}

CTLA, Cytotoxic T-lymphocyte-associated antigen; PD-L1, programmed death-ligand 1.

tional response to persistent WHV infection and WHV-induced HCC. Very recently, this analysis revealed that WHV does not induce significant intrahepatic gene expression changes during the early-acute stage of infection (week 8). These findings correspond to findings in chimpanzees infected with HBV (Wieland et al. 2004). At week 14 of infection, resolution was associated with induction markers of activated cytotoxic T cells. At this time point, high-level expression of programmed death-1 (PD-1) and various other inhibitory T-cell receptors, which likely act to minimize liver damage by cytotoxic T cells during viral clearance, were detected. The IFN- $\gamma$ signaling response was comparable to that in chronically infected animals (Fletcher et al. 2012).

Liu et al. have also performed de novo woodchuck transcriptome assembly by using deep sequencing technology (J Liu, unpubl.). 
M. Roggendorf et al.

With the help of this advanced sequencing technology, sequence information of important immune genes, such as APOBEC3 of woodchucks, has been revealed. It has been shown that upregulation of APOBEC3 led to specific and nonhepatotoxic degradation of nuclear HBV covalently closed circular DNA (cccDNA) (Lucifora et al. 2014). Therefore, future cloning and characterizing of APOBEC3 in the woodchuck model has therapeutic values for CHB. In summary, these efforts in establishing the translational value of the woodchuck model can provide new insight into characterizing immune pathways that may play a role in the persistence of HBV infection.

\section{EVALUATION OF T-CELL RESPONSE IN THE WOODCHUCK MODEL}

Monitoring of virus-specific CD4 and CD8 T-cell response is a prerequisite for immunotherapeutic approaches in woodchucks as an appropriate $\mathrm{T}$-cell response against hepatitis $\mathrm{B}$ is essential for resolution of the infection.

For many years, the immunological studies ofWHV infection in woodchucks were restricted to evaluation of antigen-specific antibodies (Roggendorf and Tolle 1995). The lack of appropriate methods to evaluate antigen-specific T-cell responses was a serious limitation of this model. Development of $2\left[{ }^{3} \mathrm{H}\right]$-adenine-based proliferation assays enabled detection of $\mathrm{T}$ helper lymphocyte responses after stimulation of woodchuck PBMCs with WHV core, surface, and $\mathrm{X}$ antigens (WHV core antigen [WHcAg], WHsAg, and WHV X antigen [WHxAg], respectively) (Menne et al. 1998, 2002b). In addition, using the $2\left[{ }^{3} \mathrm{H}\right]$-adenine-based proliferation assay in PBMCs from acutely infected animals, several T-helper epitopes within WHcAg were identified (Menne et al. 1998, 2002b).

Significant progress in studying T-cell response in the woodchuck model was achieved by introduction of the flow cytometric CD107a degranulation assay that enables the detection of WHV-specific cytotoxic T lymphocyte cells (CTLs) in woodchuck PBMCs and splenocytes (Frank et al. 2007). Several studies showed that detection of CD107a, as a degranulation mark- er, is a suitable method for determination of antigen-specific CTLs (Betts et al. 2003; Rubio et al. 2003). The assay enables detection of WHV-specific CTLs based on their granule-dependent effector function. CD107a molecule (also known as lysosomal-associated membrane protein 1 [LAMP1]) is a glycoprotein located in membranes of cytolytic granules. Recognition of the infected cells by CTLs and degranulation process results in the exposure of CD107a molecule on the CTL surface, where it can be stained with specific antibodies. Woodchuck CD107a can be stained by cross-reactive anti-mouse CD107a antibody, which enables detection of the woodchuck CTLs by flow cytometry.

Introduction of the immunological tools for studying the T-cell response in woodchucks revealed a significant similarity between the pathogenesis of WHV infection in woodchucks and $\mathrm{HBV}$ infections in humans. It was shown that acute self-limiting and resolved WHV infections correlate with robust multifunctional T-helper and cytotoxic T-cell responses, whereas WHV chronic carriers show weak or no virusspecific T-cell responses against the virus (Menne et al. 1998, 2002b; Frank et al. 2007). Moreover, these studies confirmed that the efficient cellular immune response to viral antigens results in liver injury, and is necessary for viral clearance. With the novel CD107a degranulation assay, an immunodominant CTL epitope within WHcAg (aa 96-110), and a CTL epitope within the WHsAg (aa 220-234; I Frank, AD Kosinska, M Roggendorf, et al., unpubl.) were characterized (Frank et al. 2007).

The establishment of assays for monitoring the cellular immune response in woodchucks is of great importance for a reliable evaluation of therapeutic and immunomodulatory strategies for treatment of $\mathrm{CHB}$ in the woodchuck model.

\section{THE WOODCHUCK -A PRECLINCAL MODEL FOR IMMUNMODULATORY APPROCHES FOR NEW THERAPIES AGAINST CHRONIC HEPADNAVIRAL INFECTIONS}

Over the past 10 years, the treatment options of chronic HBV infection improved greatly. There 
are two types of antiviral therapies currently available for chronic HBV-treatment with pegylated IFN- $\alpha$ (PEG-IFN- $\alpha$ ) and nucleot $(s)$ ide analogs, such as entecavir (ETV) and tenofovir. However, treatment with PEG-IFN- $\alpha$ leads to a sustained antiviral response in only $\sim 30 \%$ of patients and is associated with side effects. The introduction of PEG-IFN- $\alpha$ in combination with nucleoside analogs did not significantly increase the rate of sustained responders (Janssen et al. 2005; Lau et al. 2005). Although treatment with nucleoside analogs improves the clinical condition of chronic $\mathrm{HBV}$ patients, it is hampered by the emergence of drug-resistant mutations, and rebounding viremia after cessation of antiviral therapy (Locarnini and Mason 2006; Zoulim and Locarnini 2009). Therefore, alternative strategies to treat chronic HBV infection are needed.

The host immune response determines whether acute $\mathrm{HBV}$ infection will progress to resolution or chronicity. A strong, multispecific T-cell response to $\mathrm{HBV}$ antigens is associated with the clearance of hepatitis B. Depletion of CD8 $\mathrm{T}$ cells in chimpanzees during acute HBV infection results in the persistence of the viremia (Thimme et al. 2003). In contrast, weak or often undetectable HBV-specific immune response correlates with HBV persistence (Jung et al. 1991; Penna et al. 1991; Rehermann and Nascimbeni 2005; Yang et al. 2010). Results of these studies provided the basis for therapeutic vaccination trials to enhance the virus-specific immune response and to overcome persistent HBV infection ( $\mathrm{Lu}$ et al. 2007, 2008a). In this review, we will describe new therapeutic vaccination strategies to treat $\mathrm{CHB}$, which may be introduced for patient treatment in the future.

Numerous clinical trials of therapeutic vaccination exploited the conventional prophylactic hepatitis B surface antigen (HBsAg)-based protein vaccines in patients. These studies showed reductions in viremia, hepatitis $B$ e antigen ( $\mathrm{HBeAg}) / \mathrm{HB}$ e antibody (anti-HBe) seroconversion, and $\mathrm{HBV}$-specific T-cell responses in some patients. However, the antiviral effect was only transient and did not lead to an effective control of the HBV (Pol et al. 1994, 2001; Couillin et al. 1999; Jung et al. 2002; Di- kici et al. 2003; Ren et al. 2003; Safadi et al. 2003; Yalcin et al. 2003).

\section{T-CELL VACCINES}

DNAvaccines are gaining popularity given their ability to induce both cellular and humoral immune responses. Several phase I clinical trials investigated the therapeutic efficacy of plasmid DNA vaccines expressing HBsAg in chronic HBV carriers. These studies provided evidences for the safety of HBV DNA vaccination. They showed that DNA vaccination can restore or activate T-cell responses. However, DNA vaccines expressing only HBsAg did not result in any significant HBV DNA suppression (ManciniBourgine et al. 2004, 2006).

According to the results of these studies, it seems that therapeutic vaccination alone is not sufficient to achieve control over HBV infections. High virus load may be responsible for the immune-tolerant status in some patients. As shown in animal models, the quantity of antigen to which the immune system is exposed can induce different degrees of functional impairment of antiviral T cells, up to physical T-cell deletion (Freeman et al. 2006; Wherry et al. 2007). This idea is supported by Boni et al. (2001, 2003), reporting that the T-cell response to HBV was successfully restored in patients treated with lamivudine. Therefore, pretreatment with nucleos(t)ide analogs has been combined with vaccination to achieve better therapeutic efficacy.

\section{THERAPEUTIC IMMUNIZATION USING RECOMBINANT VIRAL VECTORS AND PRIME-BOOST STRATEGY}

Previous results from therapeutic vaccination trials on woodchucks, chimpanzees, and humans indicated that the licensed vaccines are not able to boost a functional antiviral T-cell response. Therefore, vaccines based on recombinant viruses have gained a great interest because of their ability to stimulate robust humoral and cellular immune responses. Preliminary results obtained from the study in chronically HBV-infected chimpanzees immunized with 
M. Roggendorf et al.

retroviral vectors, based on Moloney murine leukemia virus, encoding hepatitis B core antigen $(\mathrm{HBcAg})$ suggested that further investigation of viral vector-based vaccines should be taken into consideration (Sallberg et al. 1998). In one experiment, one of three therapeutically immunized chronic carrier chimpanzees cleared the virus and showed $\mathrm{HBeAg}$ seroconversion (Sallberg et al. 1998). Significant alanine aminotransferase (ALT) elevations observed in this animal implicated restoration of HBV-specific cytotoxic and humoral responses without causing fulminant hepatitis. Moreover, the other two chimpanzees showed high anti-HBe titers after the therapy and one of them HBcAg-specific CTLs (Sallberg et al. 1998). This study shows not only the benefit of using the recombinant viral vectors for treatment of chronic HBV infection in a primate model, but also the possible advantage of using core antigen-based therapeutic vaccines. Nevertheless, usage of another recombinant virus as a vaccine carrier could be a more reasonable choice, as several clinical trials suggested that gene therapy with traditional retroviral vectors can lead to oncogenesis (HaceinBey-Abina et al. 2003; Schwarzwaelder et al. 2007).

Recombinant adenoviruses proved to elicit a vigorous and sustained humoral and T-cell responses to expressed antigens that are considered to be crucial for clearance of persistent viral diseases (Shiver et al. 2002; Zakhartchouk et al. 2005). Adenoviral vectors not only deliver the antigens of interest, but also act as natural adjuvants causing DCs maturation, enhanced antigen presentation, and secretion of antiviral cytokines, such as IFN- $\alpha$, TNF- $\alpha$, and IL-6 (Morelli et al. 2000). However, even single immunization with recombinant adenoviruses may induce immunity, predominantly neutralizing antibodies, against the vector itself. The negative effect of adenovirus-induced immunity against the vaccine, mostly when the therapy requires multiple dosages, may be overcome by heterologous prime-boost regimens. In particular, priming immunizations with a plasmid DNA vaccine followed by a booster vaccination with adenoviral (AdV) seems to be a very promising strategy. DNA prime-adenovirus boost regimens proved to induce more robust and potent immune responses in comparison to plasmid DNA alone and provided protection against the pathogen challenge in several animal models of infectious diseases (Sullivan et al. 2000; Casimiro et al. 2005; Xin et al. 2005).

Recently, our group has investigated whether a heterologous prime-boost immunization strategy using plasmid DNA and recombinant adenoviral vectors may improve the efficacy of the therapeutic vaccination in $\mathrm{CHB}$ in the woodchuck model. A new DNA plasmid (pCGWHc), an adenoviral serotype 5 vector (Ad5WHc), and a chimeric Ad5 displaying Ad35 fiber (Ad35WHc) showing that high expression levels of WHcAg were constructed (Kosinska et al. 2012). Increased antigen expression was achieved by insertion of an intron sequence in the expression cassette of the vaccine. Immunizations of mice with the DNA prime$\mathrm{AdV}$ boost method, resulted in more vigorous and multispecific T-cell responses in comparison to immunization with plasmid DNA alone. Moreover, immunization of naïve woodchucks with pCGWHc plasmid or AdVs induced a significant WHcAg-specific degranulation response before the challenge, which had not been detected so far. Consistently, this response led to a rapid induction of anti-WHs antibodies and control of infection after the challenge (Kosinska et al. 2012). These results showed that high-antigen expression levels and the DNA prime-AdV boost immunization protocol improved the T-cell response in mice and induced significant T-cell responses in woodchucks.

The DNA prime-AdV boost immunization strategy was further used as a therapeutic vaccine against chronic WHV infection in combination with antiviral treatment with ETV. Six chronically WHV-infected woodchucks were treated for 23 wk with ETV. Initially, the drug was administered for $12 \mathrm{wk}$ at a dosage of $1.4 \mathrm{mg} /$ wk by osmotic pumps implanted surgically under the skin of the animals. From week 8 to 23 of the therapy, subcutaneous injections of $1 \mathrm{mg}$ of ETV were performed twice a week. Starting from week 8, four of the six ETV-treated animals received, subsequently, nine intramuscular immunizations with DNA 
plasmids, expressing WHcAg (pCGWHc) and WHsAg ( pWHsIm), Ad5WHc, and Ad35WHc. The combination therapy of ETV treatment and DNA prime-AdV boost immunization in chronic WHV carriers resulted in WHsAg- and WHcAg-specific T-helper and cytotoxic T-cell responses, which were not detectable in ETVonly treated controls. Woodchucks receiving the combination therapy showed a prolonged suppression of WHV replication and lower WHsAg levels compared with controls. Moreover, two of four immunized carriers remained WHV negative after the end of ETV treatment and developed anti-WHs antibodies (Kosinska et al. 2013). These data are encouraging and show that the combined antiviral and vaccination approach efficiently elicited sustained immunological control of chronic hepadnaviral infection in woodchucks. In addition, these results implicate the feasibility and usefulness of the immunotherapeutic strategies for the treatment of chronically $\mathrm{HBV}$-infected patients.

\section{COMBINING THERAPEUTIC VACCINATION AND MODULATION OF T-CELL FUNCTION}

The specific CTL response in patients with chronic HBV infection is generally weak or totally undetectable. This inability to mount protective CTL responses is believed to be a crucial determinant of viral persistence. Although it has been shown that nucleoside analog treatment can induce the recovery of HBV-specific cytotoxic T-cell activity in patients (Boni et al. 2001), this effect is only transient (Boni et al. 2003). Those findings are consistent with our data obtained from the woodchuck model in which ETV treatment alone only induced either transient CTL responses (Kosinska et al. 2013) or no responses at all (Liu et al. 2014). Therefore, instead of nucleoside analog treatment alone, additional treatments, which can potently enhance T-cell responses, need to be pursued.

Recent studies in chronic virus infection models indicate that the interaction between PD-1 and its ligands plays a critical role in Tcell exhaustion (Barber et al. 2006; Maier et al. 2007; Finnefrock et al. 2009; Velu et al. 2009). In many human chronic infections, including HBV, up-regulation of PD-1 on virus-specific $\mathrm{T}$ cells was observed, and restoration of the T-cell function has been achieved by blocking the PD-1/PD-ligand 1 (PD-L1) interaction in vitro (Day et al. 2006; Freeman et al. 2006; Petrovas et al. 2006; Trautmann et al. 2006; Boni et al. 2007; Penna et al. 2007; Pilli et al. 2007). PD-L1 blockade was originally described in vivo in lymphochoriomeningitis virus-infected mice. It has now been investigated in vivo for chronic HBV infection in transgenic mice and for HCV infections in chimpanzees (Fuller et al. 2013) and recently also in patients (Gardiner et al. 2013). Experiments in chimpanzees with chronic HCV infection, WHV transgenic mice, and patients with chronic HCV infection using PD-L1 antibody without additional stimulation of the T-cell response had little effect. PD-1 blockade likely requires a critical threshold of preexisting virus-specific $\mathrm{T}$ cells in liver and warrants consideration of therapeutic vaccination strategies in combination with PD-1 blockade to broaden narrow CD4/CD8 T-cell responses (Fuller et al. 2013).

In line with these findings, Zhang et al. and Liu et al. successfully cloned and characterized woodchuck PD-1/PD-L system in the WHV infection woodchuck model (Zhang et al. 2011; Liu et al. 2014). In vitro blockade of woodchuck PD-1/PD-L1 pathway by using a rabbit polyclonal $\mathrm{PD}-\mathrm{L} 1-b l o c k i n g$ antibody $(\alpha \mathrm{PD}-\mathrm{L} 1)$ could partially restore the T-cell function in WHV-infected woodchucks (Zhang et al. 2011). Moreover, in vivo blockade of PD1/PD-L1 pathway on CD8 T cells, in combination with ETV treatment and DNAvaccination, synergistically enhanced the function of virusspecific T cells (Fig 1). The combination therapy potently suppressed WHV replication, leading to sustained immunological control of viral infection, anti-WHs antibody development, and complete viral clearance in some woodchucks (Liu et al. 2014).

\section{CONCLUSION AND SUMMARY}

The aim of therapeutic vaccination and/or the immunomodulatory therapy in $\mathrm{CHB}$ is to in- 
M. Roggendorf et al.

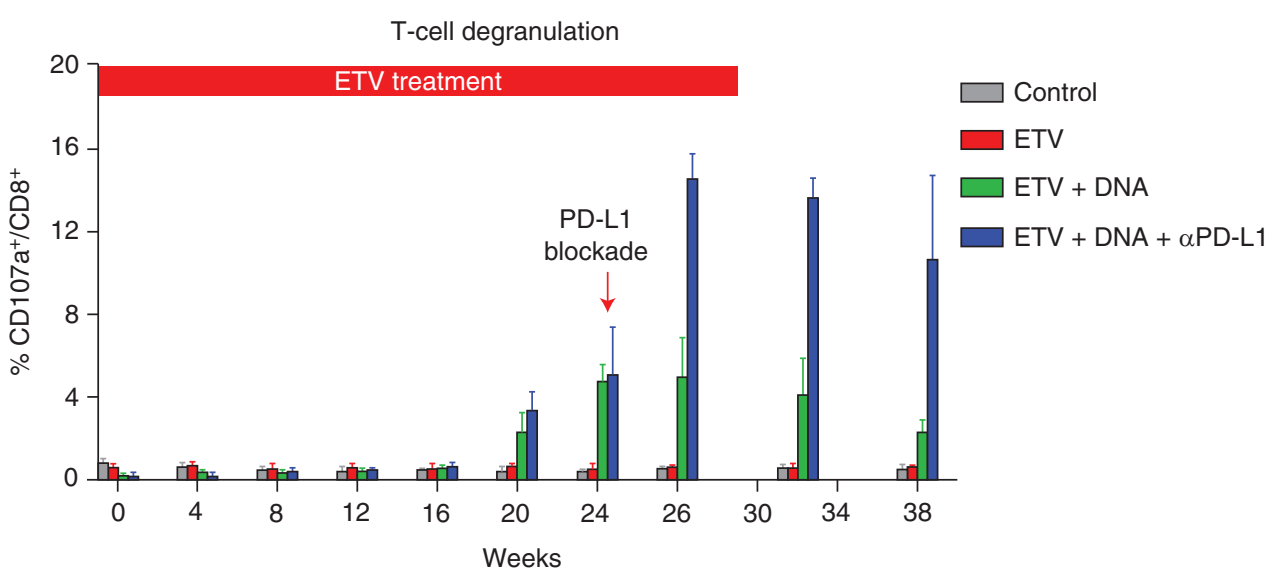

Figure 1. The kinetics of woodchuck hepatitis virus (WHV) core antigen (WHcAg)-specific T-cell responses to triple therapy in chronic WHV carriers. WHcAg-specific T-cell responses of differently treated woodchucks were analyzed by CD107a degranulation assay. The kinetics of WHcAg-specific CD8 T-cell response of four differently treated groups of woodchucks is presented. Control, control group without any treatment; entecavir (ETV), ETVonly treated group; ETV + DNA, ETV in combination with DNA vaccinations; ETV + DNA + Apd-L1, ETV and DNA vaccination in combination with anti-programmed death-ligand 1 (PD-L1) antibody treatment.

duce virus-specific CD4 and CD8 T-cell response in patients to down-regulate viral replication and elimination of infected hepatocytes. These B- and T-cell responses should be able to completely block viral replication and spread of virus over prolonged time periods until the patient can resolve the infection. Residual infected cells may carry cccDNA as it happens in patients after acute resolving infection (Rehermann et al. 1996).

In animal studies described in this review, combining prime-boost immunization and antiviral treatment seems to be sufficient in some animals to completely eliminate virus including cccDNA (Table 3). In addition, a specific $\mathrm{B}$-cell response is needed to induce antiHBs antibodies to prevent reinfection of naïve hepatocytes.

Blockade of PD-1/PD-L1 interactions increased $\mathrm{HBcAg}$-specific IFN- $\gamma$ production in intrahepatic $\mathrm{T}$ lymphocytes. Furthermore, blocking the interaction of PD-1 with PD-L1 by an anti-PD-1 monoclonal antibody (mAb) reversed the exhausted phenotype in intrahepatic T lymphocytes and cleared WHV in vivo in chronic viral infections.

These studies show, for the first time, that antiviral treatment in combination with thera- peutic vaccination or triple therapy with additional PD-L1 blockade potently boosts virusspecific CD8 T-cell responses and promotes viral control during chronic hepadnaviral infection. Further studies in a larger number of chronic carriers need to be conducted to investigate whether the rate of virus elimination could be significantly enhanced. Our results may lay a foundation for initiating a dual therapy (combination of nucleoside analog and PDL1 blockade) or a triple therapy (combination of nucleoside analog, DNA vaccine, and PD-L1 blockade) in chronic HBV patients.

The negative regulation of T-cell function involves numerous receptor and ligand interactions in separate cellular compartments at different phases of the immune response. Recent studies have suggested that multiple inhibitory receptors other than PD-1, such as CTLA-4 (Schurich et al. 2011), TIM-3 (Wu et al. 2012), and LAG-3 (Li et al. 2013), could play important roles in T-cell exhaustion during persistent $\mathrm{HBV}$ infection. These observations suggest that there may be a synergy between blockade of the various inhibitory pathways and encourage the examination of combinatorial strategies for treatment of woodchucks with chronic WHV and then in patients with chronic HBV. 
The Woodchuck as a Model for Chronic HBV Infection

Table 3. Summary of four preclinical studies on therapeutic vaccination performed in the woodchuck

\begin{tabular}{|c|c|c|c|c|c|c|c|}
\hline \multirow[b]{2}{*}{ Study } & \multirow[b]{2}{*}{$\begin{array}{l}\text { Number } \\
\text { of treated } \\
\text { animals }\end{array}$} & \multirow[b]{2}{*}{$\begin{array}{l}\text { Antiviral } \\
\text { treatment }\end{array}$} & \multirow[b]{2}{*}{$\begin{array}{l}\text { Duration } \\
\text { month }\end{array}$} & \multirow[b]{2}{*}{ Vaccine } & \multirow[b]{2}{*}{$\begin{array}{l}\text { Number } \\
\text { of shots }\end{array}$} & \multicolumn{2}{|c|}{ Outcome } \\
\hline & & & & & & $\begin{array}{l}\text { Delayed } \\
\text { rebound }\end{array}$ & $\begin{array}{c}\text { Woodchuck } \\
\text { hepatitis virus } \\
\text { DNA- } \\
\text { negative } \\
\text { in follow-up }\end{array}$ \\
\hline Lu et al. 2007 & 9 & ETV $0.5 \mathrm{mg} / \mathrm{kg}$ & 6 & $\begin{array}{l}\text { DNA vaccine, } \\
\text { WhsAg, WhcAg }\end{array}$ & 6 & $9 / 9$ & $1 / 7(14.3 \%)$ \\
\hline $\begin{array}{l}\text { M Lu et al., } \\
\text { unpubl. }\end{array}$ & 6 & ETV $0.2 \mathrm{mg}$ & 12 & $\begin{array}{l}\text { DNA vaccine, } \\
\text { WhsAg, WhcAg }\end{array}$ & 12 & $6 / 6$ & $2 / 6(33.3 \%)$ \\
\hline $\begin{array}{l}\text { Kosinska et al. } \\
2013\end{array}$ & 5 & ETV $0.2 \mathrm{mg} / \mathrm{kg}$ & 6 & $\begin{array}{l}\text { DNA vaccine, } \\
\text { WhcAg, } \\
\text { Adenoviral }\end{array}$ & 10 & $4 / 4$ & $2 / 4(50 \%)$ \\
\hline Liu et al. 2014 & 3 & ETV $0.2 \mathrm{mg} / \mathrm{kg}$ & 6 & $\begin{array}{l}\text { DNA vaccine, } \\
\text { WhsAg, WhcAg, } \\
\text { Anti-PD-L1 }\end{array}$ & 12 & $3 / 3$ & $2 / 3(66.7 \%)$ \\
\hline Total & $\begin{array}{l}23 \text { vaccin } \\
10 \text { contro }\end{array}$ & $\begin{array}{l}\text { ated animals } \\
l \text { animals; four stu }\end{array}$ & udies & & & $\begin{array}{c}23 / 23 \\
0 / 10\end{array}$ & $\begin{array}{c}7 / 21(33.3 \%) \\
0 / 10\end{array}$ \\
\hline
\end{tabular}

ETV, entecavir.

Current progress indicates the feasibility of therapeutic vaccination with or without additional immune modulation for treatment of chronic HBV infection. The increasing number of available vaccine formulations raises a crucial question: What is the optimal scheme of the therapeutic strategy? According to the studies reviewed above, the following steps should be taken to achieve a potent therapeutic effect: (1) reducing viral load by antiviral treatment; (2) inducing antiviral T-cell and/or B-cell responses by vaccinations; and (3) combining immunomodulation methods to amplify and maintain T-cell functions (Fig. 2). In addition, proper design of antigens for vaccination is also important for the development of an effective regimen of immune therapy against HBV. It has been noticed that satisfactory therapeutic effects were not reported in studies using HBsAg-based prophylactic vaccines. In the meantime, evidence has been obtained that $\mathrm{HBcAg}$-specific immunity is endowed with antiviral and liver protecting capacities in $\mathrm{CHB}$ patients and animal models. Therefore, it remains to be investigated which factors influence the effect of therapeutic vaccination. Understanding these issues will be helpful for the translation of recent progress for clinical use of therapeutic vaccination.

\section{UNRESOLVED PROBLEMS}

The viral load seems to be one of the reasons for tolerance of $\mathrm{T}$ cells against $\mathrm{HBV}$ antigens in CHB. The treatment with nucleoside analogs can reduce replicative forms of the virus by blocking reverse transcription and formation and release of new viral particles. This pretreatment seems to be a prerequisite that viralspecific CD8 and CD4 T-cell response can be induced by vaccination, and their function can be guaranteed by blocking PD-1 and PDL1 interaction. However, the template for transcription of mRNA for the $S$ protein and the core protein of the cccDNA in the nucleus is not reduced by antiviral treatment. Therefore, HBsAg and $\mathrm{HBcAg} / \mathrm{HBeAg}$ are still translated at high level. One option to reduce the protein load is the application of small interfering RNAs (siRNAs) of a length of 21 to 23 nucleotides that lead to the sequence-specific degradation of homologous mRNA. Using this RNA interference (RNAi) with chemically synthesized or vectorexpressed siRNAs, many clinically relevant vi- 
M. Roggendorf et al.

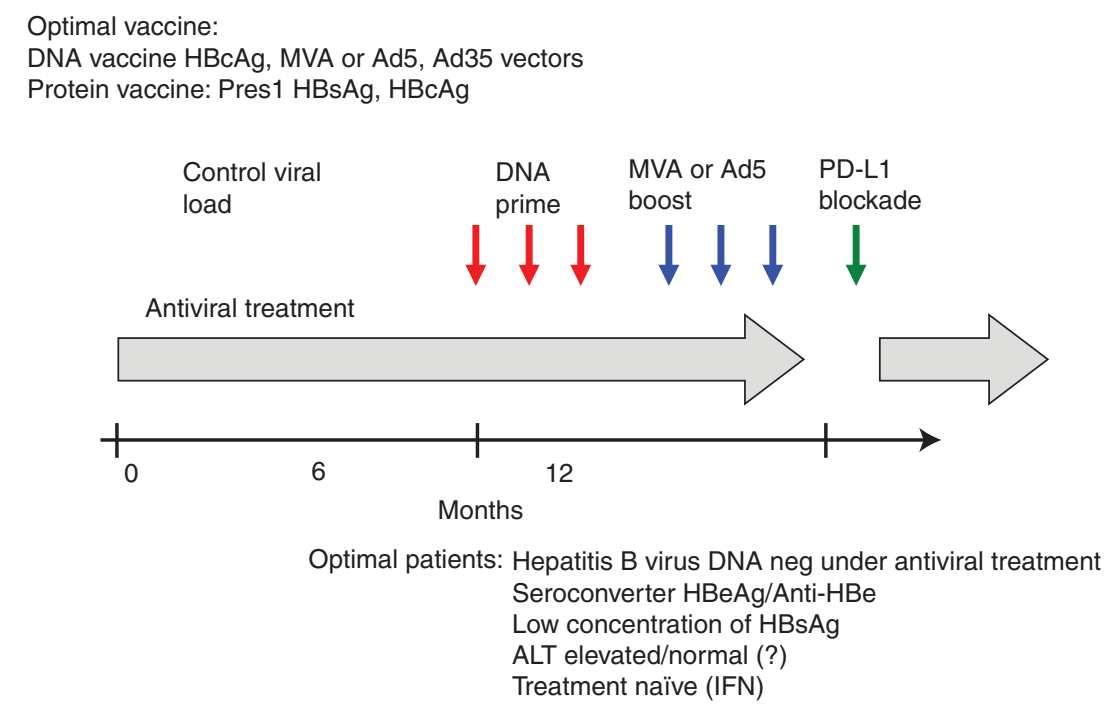

Figure 2. Strategies for therapeutic vaccination and/or immunomodulation in patients with chronic hepatitis B (CHB). Option 1: Combination of antiviral treatment nucleos(t)ide and prime-boost vaccination. Option 2: Combination of antiviral treatment nucleos(t)ide and anti-programmed death-ligand 1 (PD-L1). Option 3: Triple therapy with antiviral treatment nucleos(t)ide and prime-boost vaccination and anti-PD-L1. HBcAg, Hepatitis B core antigen; MVA, modified vaccinia Ankara; HBsAg, hepatitis B surface antigen; MVA, modified vaccinia Ankara; HBsAg, hepatitis B surface antigen; HBV, hepatitis B virus; HBeAG, hepatitis B e antigen; ALT, alanine aminotransferase; IFN, interferon.

ruses including the human immunodeficiency virus, HBV, and HCV could be inhibited. The degradation of mRNA reduces the translation of proteins. In vitro experiments showed that significant silencing of WHV transcripts can be achieved (Meng et al. 2009). However, so far, in vivo studies have not been performed to show that this technology can achieve a significant reduction of expression of WHV proteins in vivo. This silencing approach, together with nucleoside analogs and stimulation of the immune system, may be used in the future for treatment of chronic HBV infection.

An alternative to regulate HBV gene expression emerged recently with the epigenetic approach. HBV minichromosome in hepatocytes is under the control of epigenetic control and its transcriptional activity could be influenced by methylation, histone acetylation, and other mechanisms (Zhang et al. 2013). Therefore, epigenetic drugs targeting these regulatory processes may potentially be used to suppress HBV gene expression and combined with therapeutic vaccinations.
The ultimate strategy to cure HBV infection would be the direct elimination of HBV cccDNA. A recent report by Lucifora et al. (2014) about the role of APOBECs in the degradation of cccDNA remains to be confirmed. Some HBV researchers raised questions about this issue and further efforts are required to verify these findings (Chisari et al. 2014; Xia et al. 2014). In any case, it will take some time to explore whether cccDNA can be directly targeted for antiviral treatment in patients.

\section{REFERENCES}

Barber DL, Wherry EJ, Masopust D, Zhu B, Allison JP, Sharpe AH, Freeman GJ, Ahmed R. 2006. Restoring function in exhausted CD8 T cells during chronic viral infection. Nature 439: 682-687.

Benhenda S, Cougot D, Neuveut C, Buendia MA. 2009. Liver cell transformation in chronic HBV infection. Viruses 1: 630-646.

Berraondo P, Garcia-Navarro R, Gonzalez-Aseguinolaza G, Vales A, Blanco-Urgoiti B, Larrea E, Riezu-Boj JI, Prieto J, Ruiz J. 2002. The woodchuck interferon- $\alpha$ system: Cloning, family description, and biologic activity. J Med Virol 68: 424-432. 
Betts MR, Brenchley JM, Price DA, De Rosa SC, Douek DC, Roederer M, Koup RA. 2003. Sensitive and viable identification of antigen-specific $\mathrm{CD} 8^{+} \mathrm{T}$ cells by a flow cytometric assay for degranulation. J Immunol Methods 281: $65-78$.

Block TM, Lu X, Mehta AS, Blumberg BS, Tennant B, Ebling M, Korba B, Lansky DM, Jacob GS, Dwek RA. 1998. Treatment of chronic hepadnavirus infection in a woodchuck animal model with an inhibitor of protein folding and trafficking. Nat Med 4: 610-614.

Boni C, Penna A, Ogg GS, Bertoletti A, Pilli M, Cavallo C, Cavalli A, Urbani S, Boehme R, Panebianco R, et al. 2001. Lamivudine treatment can overcome cytotoxic T-cell hyporesponsiveness in chronic hepatitis B: New perspectives for immune therapy. Hepatology 33: 963-971.

Boni C, Penna A, Bertoletti A, Lamonaca V, Rapti I, Missale G, Pilli M, Urbani S, Cavalli A, Cerioni S, et al. 2003. Transient restoration of anti-viral $\mathrm{T}$ cell responses induced by lamivudine therapy in chronic hepatitis B. $J$ Hepatol 39: 595-605.

Boni C, Fisicaro P, Valdatta C, Amadei B, Di Vincenzo P, Giuberti T, Laccabue D, Zerbini A, Cavalli A, Missale G, et al. 2007. Characterization of hepatitis B virus (HBV)specific T-cell dysfunction in chronic HBV infection. $J$ Virol 81: 4215-4225.

Botta A, Lu M, Zhen X, Kemper T, Roggendorf M. 2000. Naturally occurring woodchuck hepatitis virus (WHV) deletion mutants in chronically WHV-infected woodchucks. Virology 277: 226-234.

Casimiro DR, Wang F, Schleif WA, Liang X, Zhang ZQ, Tobery TW, Davies ME, McDermott AB, O'Connor DH, Fridman A, et al. 2005. Attenuation of simian immunodeficiency virus SIVmac239 infection by prophylactic immunization with DNA and recombinant adenoviral vaccine vectors expressing Gag. J Virol 79: 15547 15555.

Chisari FV, Mason WS, Seeger C. 2014. Virology. Comment on "Specific and nonhepatotoxic degradation of nuclear hepatitis B virus cccDNA." Science 344: 1237.

Chomel B, Trepo C, Pichoud C, Jacquet C, Boulay P, Joubert L. 1984. Spontaneous and experimental infection of alpine marmots (Marmota marmota) by the North American woodchuck hepatitis virus (Marmota monax). Initial results. Comp Immunol Microbiol Infect Dis 7: 179194.

Cote PJ, Toshkov I, Bellezza C, Ascenzi M, Roneker C, Ann Graham L, Baldwin BH, Gaye K, Nakamura I, Korba BE, et al. 2000. Temporal pathogenesis of experimental neonatal woodchuck hepatitis virus infection: Increased initial viral load and decreased severity of acute hepatitis during the development of chronic viral infection. Hepatology 32: 807-817.

Couillin I, Pol S, Mancini M, Driss F, Brechot C, Tiollais P, Michel ML. 1999. Specific vaccine therapy in chronic hepatitis B: Induction of $\mathrm{T}$ cell proliferative responses specific for envelope antigens. J Infect Dis 180: 15-26.

Crettaz J, Otano I, Ochoa-Callejero L, Benito A, Paneda A, Aurrekoetxea I, Berraondo P, Rodriguez-Madoz JR, Astudillo A, Kreppel F, et al. 2009. Treatment of chronic viral hepatitis in woodchucks by prolonged intrahepatic expression of interleukin-12. J Virol 83: 2663-2674.
Cullen JM, Smith SL, Davis MG, Dunn SE, Botteron C, Cecchi A, Linsey D, Linzey D, Frick L, Paff MT, et al. 1997. In vivo antiviral activity and pharmacokinetics of (-)-cis-5-fluoro-1-[2-(hydroxymethyl)-1,3-oxathiolan5 -yl]cytosine in woodchuck hepatitis virus-infected woodchucks. Antimicrob Agents Chemother 41: 20762082.

Dahmen U, Dirsch O, Li J, Fiedle M, Lu M, Rispeter K, Picucci M, Broelsch CE, Roggendorf M. 2004. Adoptive transfer of immunity: A new strategy to interfere with severe hepatitis virus reinfection after woodchuck liver transplantation. Transplantation 77: 965-972.

Day CL, Kaufmann DE, Kiepiela P, Brown JA, Moodley ES, Reddy S, Mackey EW, Miller JD, Leslie AJ, DePierres C, et al. 2006. PD-1 expression on HIV-specific T cells is associated with T-cell exhaustion and disease progression. Nature 443: 350-354.

Di Q, Summers J, Burch JB, Mason WS. 1997. Major differences between WHV and HBV in the regulation of transcription. Virology 229: 25-35.

Dikici B, Bosnak M, Ucmak H, Dagli A, Ece A, Haspolat K. 2003. Failure of therapeutic vaccination using hepatitis $B$ surface antigen vaccine in the immunotolerant phase of children with chronic hepatitis B infection. J Gastroenterol Hepatol 18: 218-222.

Fan H, Zhu Z, Wang Y, Zhang X, Lu Y, Tao Y, Fan W, Wang Z, Wang H, Roggendorf M, et al. 2012. Molecular characterization of the type I IFN receptor in two woodchuck species and detection of its expression in liver samples from woodchucks infected with woodchuck hepatitis virus (WHV). Cytokine 60: 179-185.

Feitelson MA, Ranganathan PN, Clayton MM, Zhang SM. 1997. Partial characterization of the woodchuck tumor suppressor, p53, and its interaction with woodchuck hepatitis virus $\mathrm{X}$ antigen in hepatocarcinogenesis. Oncogene 15: $327-336$

Finnefrock AC, Tang A, Li F, Freed DC, Feng M, Cox KS, Sykes KJ, Guare JP, Miller MD, Olsen DB, et al. 2009. PD1 blockade in rhesus macaques: Impact on chronic infection and prophylactic vaccination. J Immunol 182: $980-$ 987.

Fletcher SP, Chin DJ, Ji Y, Iniguez AL, Taillon B, Swinney DC, Ravindran P, Cheng DT, Bitter H, Lopatin U, et al. 2012. Transcriptomic analysis of the woodchuck model of chronic hepatitis B. Hepatology 56: 820-830.

Fourel G, Couturier J, Wei Y, Apiou F, Tiollais P, Buendia MA. 1994. Evidence for long-range oncogene activation by hepadnavirus insertion. EMBO J 13: 2526-2534.

Frank I, Budde C, Fiedler M, Dahmen U, Viazov S, Lu M, Dittmer U, Roggendorf M. 2007. Acute resolving woodchuck hepatitis virus (WHV) infection is associated with a strong cytotoxic T-lymphocyte response to a single WHV core peptide. J Virol 81: 7156-7163.

Freeman GJ, Wherry EJ, Ahmed R, Sharpe AH. 2006. Reinvigorating exhausted HIV-specific T cells via PD-1-PD1 ligand blockade. J Exp Med 203: 2223-2227.

Fuller MJ, Callendret B, Zhu B, Freeman GJ, Hasselschwert DL, Satterfield W, Sharpe AH, Dustin LB, Rice CM, Grakoui A, et al. 2013. Immunotherapy of chronic hepatitis C virus infection with antibodies against programmed cell death-1 (PD-1). Proc Natl Acad Sci 110: 15001-15006. 
M. Roggendorf et al.

Galibert F, Chen TN, Mandart E. 1981. Localization and nucleotide sequence of the gene coding for the woodchuck hepatitis virus surface antigen: Comparison with the gene coding for the human hepatitis B virus surface antigen. Proc Natl Acad Sci 78: 5315-5319.

Garcia-Navarro R, Blanco-Urgoiti B, Berraondo P, Sanchez de la Rosa R, Vales A, Hervas-Stubbs S, Lasarte JJ, Borras F, Ruiz J, Prieto J. 2001. Protection against woodchuck hepatitis virus (WHV) infection by gene gun coimmunization with WHV core and interleukin-12. J Virol 75: 9068-9076.

Gardiner D, Lalezari J, Lawitz E, DiMicco M, Ghalib R, Reddy KR, Chang KM, Sulkowski M, Marro SO, Anderson J, et al. 2013. A randomized, double-blind, placebocontrolled assessment of BMS-936558, a fully human monoclonal antibody to programmed death-1 (PD-1), in patients with chronic hepatitis $C$ virus infection. PLOS ONE 8: e63818.

Genovesi EV, Lamb L, Medina I, Taylor D, Seifer M, Innaimo S, Colonno RJ, Clark JM. 2000. Antiviral efficacy of lobucavir (BMS-180194), a cyclobutyl-guanosine nucleoside analogue, in the woodchuck (Marmota monax) model of chronic hepatitis B virus (HBV) infection. Antiviral Res 48: 197-203.

Guo JT, Zhou H, Liu C, Aldrich C, Saputelli J, Whitaker T, Barrasa MI, Mason WS, Seeger C. 2000. Apoptosis and regeneration of hepatocytes during recovery from transient hepadnavirus infections. J Virol 74: 1495-1505.

Guy CS, Mulrooney-Cousins PM, Churchill ND, Michalak TI. 2008. Intrahepatic expression of genes affiliated with innate and adaptive immune responses immediately after invasion and during acute infection with woodchuck hepadnavirus. J Virol 82: 8579-8591.

Hacein-Bey-Abina S, Von Kalle C, Schmidt M, McCormack MP, Wulffraat N, Leboulch P, Lim A, Osborne CS, Pawliuk R, Morillon E, et al. 2003. LMO2-associated clonal T cell proliferation in two patients after gene therapy for SCID-X1. Science 302: 415-419.

Hervas-Stubbs S, Lasarte JJ, Sarobe P, Vivas I, Condreay L, Cullen JM, Prieto J, Borras-Cuesta F. 2001. T-helper cell response to woodchuck hepatitis virus antigens after therapeutic vaccination of chronically infected animals treated with lamivudine. J Hepatol 35: 105-111.

Hodgson PD, Grant MD, Michalak TI. 1999. Perforin and Fas/Fas ligand-mediated cytotoxicity in acute and chronic woodchuck viral hepatitis. Clin Exp Immunol 118: $63-70$.

Janssen HL, van Zonneveld M, Senturk H, Zeuzem S, Akarca US, Cakaloglu Y, Simon C, So TM, Gerken G, de Man RA, et al. 2005. Pegylated interferon $\alpha-2 b$ alone or in combination with lamivudine for HBeAg-positive chronic hepatitis B: A randomised trial. Lancet 365: 123 129.

Jiang M, Liu J, Zhang E, Meng Z, Wang B, Roggendorf M, Yang D, Lu M, Xu Y. 2012. Molecular characterization of woodchuck interleukin-10 receptor and enhanced function of specific $\mathrm{T}$ cells from chronically infected woodchucks following its blockade. Comp Immunol Microbiol Infect Dis 35: 563-573.

Jung MC, Spengler U, Schraut W, Hoffmann R, Zachoval R, Eisenburg J, Eichenlaub D, Riethmuller G, Paumgartner G, Ziegler-Heitbrock HW, et al. 1991. Hepatitis B virus antigen-specific T-cell activation in patients with acute and chronic hepatitis B. J Hepatol 13: 310-317.

Jung MC, Gruner N, Zachoval R, Schraut W, Gerlach T, Diepolder H, Schirren CA, Page M, Bailey J, Birtles E, et al. 2002. Immunological monitoring during therapeutic vaccination as a prerequisite for the design of new effective therapies: Induction of a vaccine-specific $\mathrm{CD}^{+}{ }^{+} \mathrm{T}$-cell proliferative response in chronic hepatitis B carriers. Vaccine 20: 3598-3612.

Kajino K, Jilbert AR, Saputelli J, Aldrich CE, Cullen J, Mason WS. 1994. Woodchuck hepatitis virus infections: Very rapid recovery after a prolonged viremia and infection of virtually every hepatocyte. J Virol 68: 5792-5803.

Korba BE, Cote P, Hornbuckle W, Tennant BC, Gerin JL. 2000. Treatment of chronic woodchuck hepatitis virus infection in the Eastern woodchuck (Marmota monax) with nucleoside analogues is predictive of therapy for chronic hepatitis B virus infection in humans. Hepatology 31: 1165-1175.

Kosinska AD, Johrden L, Zhang E, Fiedler M, Mayer A, Wildner O, Lu M, Roggendorf M. 2012. DNA primeadenovirus boost immunization induces a vigorous and multifunctional T-cell response against hepadnaviral proteins in the mouse and woodchuck model. J Virol 86: 9297-9310.

Kosinska AD, Zhang E, Johrden L, Liu J, Seiz PL, Zhang X, Ma Z, Kemper T, Fiedler M, Glebe D, et al. 2013. Combination of DNA prime-Adenovirus boost immunization with entecavir elicits sustained control of chronic hepatitis B in the woodchuck model. PLoS Pathog 9: e1003391.

Lau GK, Piratvisuth T, Luo KX, Marcellin P, Thongsawat S, Cooksley G, Gane E, Fried MW, Chow WC, Paik SW, et al. 2005. Peginterferon $\alpha-2 a$, lamivudine, and the combination for HBeAg-positive chronic hepatitis B. $N$ Engl J Med 352: 2682-2695.

Li DH, Newbold JE, Cullen JM. 1996. Natural populations of woodchuck hepatitis virus contain variant precore and core sequences including a premature stop codon in the epsilon motif. Virology 220: 256-262.

Li DH, Havell EA, Brown CL, Cullen JM. 2000. Woodchuck lymphotoxin- $\alpha,-\beta$ and tumor necrosis factor genes: Structure, characterization and biological activity. Gene 242: 295-305.

Li FJ, Zhang Y, Jin GX, Yao L, Wu DQ. 2013. Expression of LAG-3 is coincident with the impaired effector function of $\mathrm{HBV}$-specific $\mathrm{CD}^{+} \mathrm{T}$ cell in HCC patients. Immunol Lett 150: 116-122.

Liu CJ, Huang YJ, Chen HL, Lin HT, Lin HL, Kuo ML, Huang JL, Chen DS, Chen PJ, Wu HL. 2009. Characterization of interleukin 8 in woodchucks with chronic hepatitis B and hepatocellular carcinoma. Genes Immun 10: $27-36$.

Liu J, Zhang E, Ma Z, Wu W, Kosinska A, Zhang X, Moller I, Seiz P, Glebe D, Wang B, et al. 2014. Enhancing virusspecific immunity in vivo by combining therapeutic vaccination and PD-L1 blockade in chronic hepadnaviral infection. PLoS Pathog 10: e1003856.

Locarnini S, Mason WS. 2006. Cellular and virological mechanisms of HBV drug resistance. J Hepatol 44: 422-431. 
Lohrengel B, Lu M, Roggendorf M. 1998. Molecular cloning of the woodchuck cytokines: TNF- $\alpha$, IFN- $\gamma$, and IL- 6 . Immunogenetics 47: 332-335.

Lohrengel B, Lu M, Bauer D, Roggendorf M. 2000. Expression and purification of woodchuck tumour necrosis factor $\alpha$. Cytokine 12: 573-577.

Lu M, Roggendorf M. 2001. Evaluation of new approaches to prophylactic and therapeutic vaccinations against hepatitis B viruses in the woodchuck model. Intervirology 44: 124-131.

Lu M, Hilken G, Kruppenbacher J, Kemper T, Schirmbeck R, Reimann J, Roggendorf M. 1999. Immunization of woodchucks with plasmids expressing woodchuck hepatitis virus (WHV) core antigen and surface antigen suppresses WHV infection. J Virol 73: 281-289.

Lu M, Lohrengel B, Hilken G, Kemper T, Roggendorf M. 2002. Woodchuck $\gamma$ interferon upregulates major histocompatibility complex class I transcription but is unable to deplete woodchuck hepatitis virus replication intermediates and RNAs in persistently infected woodchuck primary hepatocytes. J Virol 76: 58-67.

Lu M, Menne S, Yang D, Xu Y, Roggendorf M. 2007. Immunomodulation as an option for the treatment of chronic hepatitis B virus infection: Preclinical studies in the woodchuck model. Expert Opin Investig Drugs 16: 787801.

Lu M, Yao X, Xu Y, Lorenz H, Dahmen U, Chi H, Dirsch O, Kemper T, He L, Glebe D, et al. 2008a. Combination of an antiviral drug and immunomodulation against hepadnaviral infection in the woodchuck model. J Virol 82: 2598 2603.

Lu Y, Xu Y, Yang D, Kemper T, Roggendorf M, Lu M. 2008b. Molecular characterization of woodchuck type I interferons and their expression by woodchuck peripheral blood lymphocytes. Cytokine 41: 127-135.

Lucifora J, Xia Y, Reisinger F, Zhang K, Stadler D, Cheng X, Sprinzl MF, Koppensteiner H, Makowska Z, Volz T, et al. 2014. Specific and nonhepatotoxic degradation of nuclear hepatitis B virus cccDNA. Science 343: 1221-1228.

Maier H, Isogawa M, Freeman GJ, Chisari FV. 2007. PD1:PD-L1 interactions contribute to the functional suppression of virus-specific $\mathrm{CD} 8^{+} \mathrm{T}$ lymphocytes in the liver. J Immunol 178: 2714-2720.

Mancini-Bourgine M, Fontaine H, Scott-Algara D, Pol S, Brechot C, Michel ML. 2004. Induction or expansion of T-cell responses by a hepatitis B DNA vaccine administered to chronic HBV carriers. Hepatology 40: 874-882.

Mancini-Bourgine M, Fontaine H, Brechot C, Pol S, Michel ML. 2006. Immunogenicity of a hepatitis B DNA vaccine administered to chronic HBV carriers. Vaccine 24: $4482-$ 4489.

Mason WS, Cullen J, Moraleda G, Saputelli J, Aldrich CE Miller DS, Tennant B, Frick L, Averett D, Condreay LD, et al. 1998. Lamivudine therapy of WHV-infected woodchucks. Virology 245: 18-32.

Meng Z, Qiu S, Zhang X, Wu J, Schreiter T, Xu Y, Yang D, Roggendorf M, Schlaak J, Lu M. 2009. Inhibition of woodchuck hepatitis virus gene expression in primary hepatocytes by siRNA enhances the cellular gene expression. Virology 384: 88-96.

Menne S, Maschke J, Tolle TK, Lu M, Roggendorf M. 1997. Characterization of T-cell response to woodchuck hepa- titis virus core protein and protection of woodchucks from infection by immunization with peptides containing a T-cell epitope. J Virol 71: 65-74.

Menne S, Maschke J, Lu M, Grosse-Wilde H, Roggendorf M. 1998. T-Cell response to woodchuck hepatitis virus (WHV) antigens during acute self-limited WHV infection and convalescence and after viral challenge. J Virol 72: 6083-6091.

Menne S, Roneker CA, Korba BE, Gerin JL, Tennant BC, Cote PJ. 2002a. Immunization with surface antigen vaccine alone and after treatment with 1-(2-fluoro-5-methyl- $\beta$-L-arabinofuranosyl)-uracil (L-FMAU) breaks humoral and cell-mediated immune tolerance in chronic woodchuck hepatitis virus infection. J Virol 76: 53055314.

Menne S, Roneker CA, Roggendorf M, Gerin JL, Cote PJ, Tennant BC. 2002b. Deficiencies in the acute-phase cellmediated immune response to viral antigens are associated with development of chronic woodchuck hepatitis virus infection following neonatal inoculation. J Virol 76: 1769-1780.

Michalak TI, Hodgson PD, Churchill ND. 2000. Posttranscriptional inhibition of class I major histocompatibility complex presentation on hepatocytes and lymphoid cells in chronic woodchuck hepatitis virus infection. J Virol 74: 4483-4494.

Morelli AE, Larregina AT, Ganster RW, Zahorchak AF, Plowey JM, Takayama T, Logar AJ, Robbins PD, Falo LD, Thomson AW. 2000. Recombinant adenovirus induces maturation of dendritic cells via an NF-кB-dependent pathway. J Virol 74: 9617-9628.

Moroy T, Marchio A, Etiemble J, Trepo C, Tiollais P, Buendia MA. 1986. Rearrangement and enhanced expression of c$m y c$ in hepatocellular carcinoma of hepatitis virus infected woodchucks. Nature 324: 276-279.

Nakamura I, Nupp JT, Cowlen M, Hall WC, Tennant BC, Casey JL, Gerin JL, Cote PJ. 2001. Pathogenesis of experimental neonatal woodchuck hepatitis virus infection: Chronicity as an outcome of infection is associated with a diminished acute hepatitis that is temporally deficient for the expression of interferon $\gamma$ and tumor necrosis factor- $\alpha$ messenger RNAs. Hepatology 33: 439_ 447.

Peek SF, Cote PJ, Jacob JR, Toshkov IA, Hornbuckle WE, Baldwin BH, Wells FV, Chu CK, Gerin JL, Tennant BC, et al. 2001. Antiviral activity of clevudine [L-FMAU, (1-(2-fluoro-5-methyl- $\beta$, L-arabinofuranosyl) uracil)] against woodchuck hepatitis virus replication and gene expression in chronically infected woodchucks (Marmota monax). Hepatology 33: 254-266.

Penna A, Chisari FV, Bertoletti A, Missale G, Fowler P, Giuberti T, Fiaccadori F, Ferrari C. 1991. Cytotoxic T lymphocytes recognize an HLA-A2-restricted epitope within the hepatitis B virus nucleocapsid antigen. J Exp Med 174: $1565-1570$.

Penna A, Pilli M, Zerbini A, Orlandini A, Mezzadri S, Sacchelli L, Missale G, Ferrari C. 2007. Dysfunction and functional restoration of HCV-specific CD8 responses in chronic hepatitis C virus infection. Hepatology 45: $588-601$.

Petrovas C, Casazza JP, Brenchley JM, Price DA, Gostick E, Adams WC, Precopio ML, Schacker T, Roederer M, 
M. Roggendorf et al.

Douek DC, et al. 2006. PD-1 is a regulator of virus-specific $\mathrm{CD}^{+} \mathrm{T}$ cell survival in HIV infection. J Exp Med 203: $2281-2292$.

Pilli M, Zerbini A, Penna A, Orlandini A, Lukasiewicz E, Pawlotsky JM, Zeuzem S, Schalm SW, von Wagner M, Germanidis G, et al. 2007. HCV-specific T-cell response in relation to viral kinetics and treatment outcome (DITTO-HCV project). Gastroenterology 133: 1132-1143.

Pol S, Driss F, Michel ML, Nalpas B, Berthelot P, Brechot C 1994. Specific vaccine therapy in chronic hepatitis B infection. Lancet 344: 342

Pol S, Nalpas B, Driss F, Michel ML, Tiollais P, Denis J, Brecho C. 2001. Efficacy and limitations of a specific immunotherapy in chronic hepatitis B. J Hepatol 34: 917-921.

Putzer BM, Stiewe T, Rodicker F, Schildgen O, Ruhm S, Dirsch O, Fiedler M, Damen U, Tennant B, Scherer C, et al. 2001. Large nontransplanted hepatocellular carcinoma in woodchucks: Treatment with adenovirus-mediated delivery of interleukin 12/B7.1 genes. J Natl Cancer Inst 93: 472-479.

Rehermann B, Nascimbeni M. 2005. Immunology of hepatitis $B$ virus and hepatitis $C$ virus infection. Nat Rev Immunol 5: 215-229.

Rehermann B, Ferrari C, Pasquinelli C, Chisari FV. 1996 The hepatitis B virus persists for decades after patients' recovery from acute viral hepatitis despite active maintenance of a cytotoxic T-lymphocyte response. Nat Med 2: 1104-1108.

Ren F, Hino K, Yamaguchi Y, Funatsuki K, Hayashi A, Ishiko H, Furutani M, Yamasaki T, Korenaga K, Yamashita S, et al. 2003. Cytokine-dependent anti-viral role of CD4positive $\mathrm{T}$ cells in therapeutic vaccination against chronic hepatitis B viral infection. J Med Virol 71: 376-384.

Roggendorf M, Tolle TK. 1995. The woodchuck: An animal model for hepatitis B virus infection in man. Intervirology 38: $100-112$.

Rubio V, Stuge TB, Singh N, Betts MR, Weber JS, Roederer M, Lee PP. 2003. Ex vivo identification, isolation and analysis of tumor-cytolytic T cells. Nat Med 9: 1377 1382.

Safadi R, Israeli E, Papo O, Shibolet O, Melhem A, Bloch A, Rowe M, Alper R, Klein A, Hemed N, et al. 2003. Treatment of chronic hepatitis B virus infection via oral immune regulation toward hepatitis B virus proteins. Am J Gastroenterol 98: 2505-2515.

Sallberg M, Hughes J, Javadian A, Ronlov G, Hultgren C, Townsend K, Anderson CG, O'Dea J, Alfonso J, Eason R, et al. 1998. Genetic immunization of chimpanzees chronically infected with the hepatitis B virus, using a recombinant retroviral vector encoding the hepatitis $\mathrm{B}$ virus core antigen. Hum Gene Ther 9: 1719-1729.

Salucci V, Lu M, Aurisicchio L, La Monica N, Roggendorf M, Palombo F. 2002. Expression of a new woodchuck IFN- $\alpha$ gene by a helper-dependent adenoviral vector in woodchuck hepatitis virus-infected primary hepatocytes. J Interferon Cytokine Res 22: 1027-1034.

Schurich A, Khanna P, Lopes AR, Han KJ, Peppa D, Micco L, Nebbia G, Kennedy PT, Geretti AM, Dusheiko G, et al. 2011. Role of the coinhibitory receptor cytotoxic T lymphocyte antigen-4 on apoptosis-prone CD8 $\mathrm{T}$ cells in persistent hepatitis B virus infection. Hepatology 53: 1494-1503.

Schwarzwaelder K, Howe SJ, Schmidt M, Brugman MH, Deichmann A, Glimm H, Schmidt S, Prinz C, Wissler $\mathrm{M}$, King DJ, et al. 2007. Gammaretrovirus-mediated correction of SCID-X1 is associated with skewed vector integration site distribution in vivo. J Clin Invest 117: 2241-2249.

Shiver JW, Fu TM, Chen L, Casimiro DR, Davies ME, Evans RK, Zhang ZQ, Simon AJ, Trigona WL, Dubey SA, et al. 2002. Replication-incompetent adenoviral vaccine vector elicits effective anti-immunodeficiency-virus immunity. Nature 415: 331-335.

Sullivan NJ, Sanchez A, Rollin PE, Yang ZY, Nabel GJ. 2000. Development of a preventive vaccine for Ebola virus infection in primates. Nature 408: 605-609.

Summers J, Smolec JM, Snyder R. 1978. A virus similar to human hepatitis $B$ virus associated with hepatitis and hepatoma in woodchucks. Proc Natl Acad Sci 75: 45334537.

Thimme R, Wieland S, Steiger C, Ghrayeb J, Reimann KA, Purcell RH, Chisari FV. 2003. CD8 ${ }^{+}$T cells mediate viral clearance and disease pathogenesis during acute hepatitis B virus infection. J Virol 77: 68-76.

Trautmann L, Janbazian L, Chomont N, Said EA, Gimmig S, Bessette B, Boulassel MR, Delwart E, Sepulveda H, Balderas RS, et al. 2006. Upregulation of PD-1 expression on HIV-specific $\mathrm{CD}^{+} \mathrm{T}$ cells leads to reversible immune dysfunction. Nat Med 12: 1198-1202.

Velu V, Titanji K, Zhu B, Husain S, Pladevega A, Lai L, Vanderford TH, Chennareddi L, Silvestri G, Freeman GJ, et al. 2009. Enhancing SIV-specific immunity in vivo by PD-1 blockade. Nature 458: 206-210.

Wang Y, Menne S, Jacob JR, Tennant BC, Gerin JL, Cote PJ. 2003. Role of type 1 versus type 2 immune responses in liver during the onset of chronic woodchuck hepatitis virus infection. Hepatology 37: 771-780.

Wang B, Lohrengel B, Lu Y, Meng Z, Xu Y, Yang D, Roggendorf M, Lu M. 2005. Molecular characterization of woodchuck interleukin 15 (wIL-15) and detection of its expression in liver samples of woodchucks infected with woodchuck hepatitis virus (WHV). Cytokine 32: 296303.

Wang BJ, Tian YJ, Meng ZJ, Jiang M, Wei BQ, Tao YQ, Fan W, Li AY, Bao JJ, Li XY, et al. 2011. Establishing a new animal model for hepadnaviral infection: Susceptibility of Chinese Marmota-species to woodchuck hepatitis virus infection. J Gen Virol 92: 681-691.

Wang B, Zhu Z, Zhu B, Wang J, Song Z, Huang S, Fan W, Tao Y, Wang Z, Wang H, et al. 2014. Nucleoside analogues alone or combined with vaccination prevent hepadnavirus viremia and induce protective immunity: Alternative strategy for hepatitis B virus post-exposure prophylaxis. Antiviral Res 105: 118-125.

Wherry EJ, Ha SJ, Kaech SM, Haining WN, Sarkar S, Kalia V, Subramaniam S, Blattman JN, Barber DL, Ahmed R. 2007. Molecular signature of $\mathrm{CD} 8^{+} \mathrm{T}$ cell exhaustion during chronic viral infection. Immunity 27: 670-684.

Wieland S, Thimme R, Purcell RH, Chisari FV. 2004. Genomic analysis of the host response to hepatitis $B$ virus infection. Proc Natl Acad Sci 101: 6669-6674. 
Wu HL, Chen PJ, Lin HK, Lee RS, Lin HL, Liu CJ, Lee PJ, Lee JJ, Chen DS. 2001. Molecular cloning and expression of woodchuck granulocyte-macrophage colony stimulating factor. J Med Virol 65: 567-575.

Wu W, Shi Y, Li S, Zhang Y, Liu Y, Wu Y, Chen Z. 2012. Blockade of Tim-3 signaling restores the virus-specific $\mathrm{CD}^{+} \mathrm{T}$-cell response in patients with chronic hepatitis B. Eur J Immunol 42: 1180-1191.

Xia Y, Lucifora J, Reisinger F, Heikenwalder M, Protzer U. 2014. Virology. Response to Comment on "Specific and nonhepatotoxic degradation of nuclear hepatitis B virus cccDNA." Science 344: 1237.

Xin KQ, Jounai N, Someya K, Honma K, Mizuguchi H, Naganawa S, Kitamura K, Hayakawa T, Saha S, Takeshita F, et al. 2005. Prime-boost vaccination with plasmid DNA and a chimeric adenovirus type 5 vector with type 35 fiber induces protective immunity against HIV. Gene Ther 12: 1769-1777.

Yalcin K, Acar M, Degertekin H. 2003. Specific hepatitis B vaccine therapy in inactive HBsAg carriers: A randomized controlled trial. Infection 31: 221-225.

Yamamoto T, Litwin S, Zhou T, Zhu Y, Condreay L, Furman P, Mason WS. 2002. Mutations of the woodchuck hepatitis virus polymerase gene that confer resistance to lamivudine and $2^{\prime}$-fluoro-5-methyl- $\beta$-L-arabinofuranosyluracil. J Virol 76: 1213-1223.

Yang D, Roggendorf M, Lu M. 2003. Molecular characterization of CD28 and cytotoxic T-lymphocyte-associated antigen 4 (CTLA-4) of woodchuck (Marmota monax). Tissue Antigens 62: 225-232.

Yang PL, Althage A, Chung J, Maier H, Wieland S, Isogawa M, Chisari FV. 2010. Immune effectors required for hepatitis B virus clearance. Proc Natl Acad Sci 107: 798-802.
Zakhartchouk AN, Liu Q, Petric M, Babiuk LA. 2005. Augmentation of immune responses to SARS coronavirus by a combination of DNA and whole killed virus vaccines. Vaccine 23: 4385-4391.

Zhang Z, Torii N, Hu Z, Jacob J, Liang TJ. 2001. X-deficient woodchuck hepatitis virus mutants behave like attenuated viruses and induce protective immunity in vivo. J Clin Invest 108: 1523-1531.

Zhang X, Meng Z, Qiu S, Xu Y, Yang D, Schlaak JF, Roggendorf M, Lu M. 2009. Lipopolysaccharide-induced innate immune responses in primary hepatocytes downregulates woodchuck hepatitis virus replication via interferon-independent pathways. Cell Microbiol 11: $1624-1637$.

Zhang E, Zhang X, Liu J, Wang B, Tian Y, Kosinska AD, Ma Z, Xu Y, Dittmer U, Roggendorf M, et al. 2011. The expression of PD-1 ligands and their involvement in regulation of $\mathrm{T}$ cell functions in acute and chronic woodchuck hepatitis virus infection. PLoS ONE 6: e26196.

Zhang X, Ma Z, Liu H, Liu J, Meng Z, Broering R, Yang D, Schlaak JF, Roggendorf M, Lu M. 2012. Role of Toll-like receptor 2 in the immune response against hepadnaviral infection. J Hepatol 57: 522-528.

Zhang X, Hou J, Lu M. 2013. Regulation of hepatitis B virus replication by epigenetic mechanisms and microRNAs. Front Genet 4: 202.

Zhou T, Saputelli J, Aldrich CE, Deslauriers M, Condreay LD, Mason WS. 1999. Emergence of drug-resistant populations of woodchuck hepatitis virus in woodchucks treated with the antiviral nucleoside lamivudine. Antimicrob Agents Chemother 43: 1947-1954.

Zoulim F, Locarnini S. 2009. Hepatitis B virus resistance to nucleos(t)ide analogues. Gastroenterology 137: 1593 1608.e1-2. 


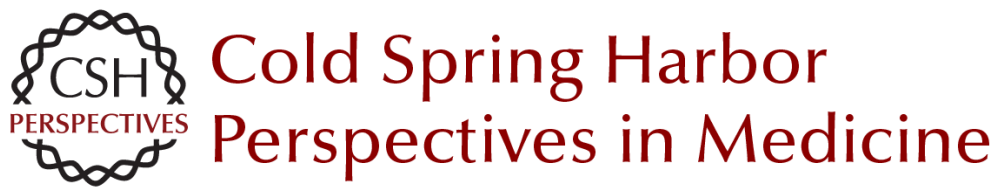

\title{
The Woodchuck, a Nonprimate Model for Immunopathogenesis and Therapeutic Immunomodulation in Chronic Hepatitis B Virus Infection
}

\author{
Michael Roggendorf, Anna D. Kosinska, Jia Liu and Mengji Lu
}

Cold Spring Harb Perspect Med 2015; doi: 10.1101/cshperspect.a021451 originally published online October 28, 2015

\section{Subject Collection The Hepatitis B and Delta Viruses}

\section{Hepatitis B Virus X and Regulation of Viral Gene Expression \\ Betty L. Slagle and Michael J. Bouchard}

The Woodchuck, a Nonprimate Model for Immunopathogenesis and Therapeutic Immunomodulation in Chronic Hepatitis B Virus Infection

Michael Roggendorf, Anna D. Kosinska, Jia Liu, et al.

Mouse Models of Hepatitis B Virus Pathogenesis Matteo lannacone and Luca G. Guidotti

Therapy of Delta Hepatitis

$$
\text { Cihan Yurdaydin and Ramazan Idilman }
$$

Immune Response in Hepatitis B Virus Infection Anthony Tan, Sarene Koh and Antonio Bertoletti Hepatitis D Virus: Introduction and Epidemiology
Mario Rizzetto

Management of Chronic Hepatitis B in Patients from Special Populations Ching-Lung Lai and Man-Fung Yuen

Hepatitis B Virus Genotypes and Variants Chih-Lin Lin and Jia-Horng Kao
Origins and Evolution of Hepatitis B Virus and

Hepatitis D Virus Margaret Littlejohn, Stephen Locarnini and Lilly Yuen

Assembly and Release of Hepatitis B Virus Lisa Selzer and Adam Zlotnick

\footnotetext{
Hepatitis D Virus Replication John M. Taylor

Treatment of Liver Cancer Chun-Yu Liu, Kuen-Feng Chen and Pei-Jer Chen

Hepatitis B Virus and Hepatitis D Virus Entry, Species Specificity, and Tissue Tropism Koichi Watashi and Takaji Wakita

Hepadnavirus Genome Replication and

Persistence Jianming Hu and Christoph Seeger

The Chimpanzee Model for Hepatitis B Virus Infection Stefan F. Wieland

Hepatitis B Virus Epidemiology Jennifer H. MacLachlan and Benjamin C. Cowie
}

For additional articles in this collection, see http://perspectivesinmedicine.cshlp.org/cgi/collection/ 